\title{
BIOCHEMICAL RESIDUES IN MILK AND MILK PRODUCTS - A REVIEW
}

\author{
P. R. RAY* AND C. SEN \\ Department of Dairy Chemistry, Faculty of Dairy Technology \\ West Bengal University of Animal and Fishery Sciences \\ Mohanpur Campus, Nadia-741 252, West Bengal, India
}

\begin{abstract}
Biochemical residues are serious threats to food safety. The major chemical residues found in milk and milk products are antibiotics, bovine growth hormones, pesticides, heavy metals, mycotoxins etc. Among these, antibiotic residue is the most dangerous one. People consuming dairy products contaminated with these residues may suffer from serious diseases like cancer, hepatopathy, kidney damage, brain tumour, cardiovascular disease etc. Some food regulatory bodies like Food and Agriculture Organization of the United Nations (FAO), World Health Organization (WHO), Codex Alimentarius Commission, European Union Food Safety Policy Committee are set up standard permeable level i.e. known as Maximum residual limit (MRL) for residues. MRL is defined as the highest level of chemical residues legally permitted in food or feed. To overcome this problem, the food industry should come up with strict food analysis system.
\end{abstract}

Key Words: Antibiotic, Growth hormone, Milk, Mycotoxin, Pesticides

\section{Introduction}

Environment plays a very important role in our daily life. Milk production and processing of milk products also have a close linkage with environment. Now a days, foods which are consumed by the human beings are mostly grown by using pesticides, hormones, antibiotics, fungicides etc. These compounds have potential to adversely affect our environment and ecology. Residues of these chemicals have high potentiality to cause harmful effects to the consumers (Tennant, 1997). These contaminants can be fatal to human beings as they are reported to cause various diseases like kidney damage, brain tumor, cardiovascular disease, hepatocellular carcinoma, hypertension, blue baby syndrome, leukemia etc (Volkmer, 2005). Bovine somatotropin hormone (BST) being used in milch animals for increasing the milk production is found to be excreted through milk (Thornley, 2001). The antibiotic residues due to use of antibiotics for treatment of mastitis may cause significant public health hazards. In addition, insecticides, herbicides, detergent, disinfectants, antibacterial drugs, anthelminthic drugs,polychlorinated biphenyls, polybrominated biphenyls, dioxins, heavy metals, mycotoxins and somatotropin hormones are detected in milk and milk products in various processing sections during collection, preparation of products, storage and distribution (Jensen, 
1995; Hubbert et al., 1996). These compounds are reported to cause Parkinsonism, Alzheimer's disease and cancer in consumers (Jahed, 2006). Milk and milk products are consumed all over the world may have adverse impact on the public health. World Health Organization (WHO), Food Agriculture Organization (FAO), Codex Alimenterius Commission (CAC) and European Economic Community (EEC) have set up norms for satisfactory daily intake and most extreme residues confined in food items (FAO/WHO, 1995). An administrative regulatory limit for antibiotic residues and other chemical residues has been enforced on the dairy business in different countries (FDA USA, 1996; Folly and Machado, 2001). The limit is known as maximum residual limit (MRL). However, it varies with different regulations as well as for different chemical residues applied to different products. Recognizable convergences of anti-microbial agents build up in milk generally contains higher than the MRLs.

\section{Source of chemical residues in milk and milk products}

The sources of chemical residues in milk and milk products are the antimicrobial drugs

Table 1. MRL of some antibiotic drugs in milk according to FSSAI regulations

\begin{tabular}{lc}
\hline \multicolumn{1}{c}{ Drugs } & $\begin{array}{c}\text { Concentration } \\
\mathbf{~ m g / L}\end{array}$ \\
\hline Sulphadimidine & 0.025 \\
Neomycin & 2.5 \\
Chlortetracycline & 0.1 \\
Ceftiofur & 0.1 \\
Ampicillin & 0.01 \\
Spectinomycin & 0.2 \\
Oxybendazole & 0.01 \\
Trimethoprim & 0.01 \\
\hline
\end{tabular}

Source: FSSA, 2006 and bovine growth hormones used for treatment of milch animal (Jahed, 2006) and contaminated feed containing insecticides, fungicides, herbicides etc (Aytenfsu et al., 2016). Mycotoxin contamination of feed occurs due to mould growth (Aytenfsu et al., 2016) whereas, contamination of heavy metals and other toxic agents occurs due to environmental pollution (Ikeda et al., 1996; Raghunath et al., 1997).

Antibiotics: Residues of most of the antibiotics used to treat mastitis in dairy animals are detected in the milk and milk products. Antibiotics are administered to the animals through intramuscular, intravenous, intramammary, intrauterine, oral and topical applications. Antimicrobial agents and or their metabolites come in to milk after administration by all these routes (Hubbert et al., 1996; Mitchel et al., 1998). Maximum residual limits (MRL) of some of the antibiotics used in dairy animals are given in Table 1.

Hormones: The pasteurized milk and purely raw milk could have insulin like growth factor (IGF-I) levels of 8.2 and $5.6 \mathrm{ng} / \mathrm{mL}$, respectively indicating that IGF-I isn't destroyed by the pasteurization procedure. The decreased (35-48\%) level of IGF-1 is detected in raw milk in comparison to pasteurized milk (FAO/WHO, 1993). As indicated by the epidemiological evidences, the elevated level of IGF-1, insulin, or both may cause colon, pancreas, endometrium, bosom and prostate tumors (Chaves and Saif, 2011). Ontsouka et al. (2003) found that concentration of prolactin in composite milk of Holstein $\times$ Sim-mental cows in day 2 (colostrum) and week 4 (mature milk) of lactation were $120 \pm 16$ and $15.4 \pm 1 \mu \mathrm{g} / \mathrm{L}$, respectively. 
Steroid hormones: Milk and milk products are the common sources of steroid hormones. Steroid hormones are lipophilic in nature and their presence in milk and milk products depends on the fat content. Food processing parameters like heating, cooling, churning do not affect the level of steroid hormones except ripening of cheese. Testosterone (0.1-0.5 mg/ $\mathrm{kg}$ ) could be detected in fresh cheese as well as ripened cheese (Hartmann et al., 1998).

The physiologic concentrations of progesterone in milk of dairy animals at various stages of oestrus cycle, day 21 of cycle, midcycle, and pregnancy were reported as 5.42, 11.36, 8.53 and $11.75 \mathrm{ng} / \mathrm{mL}$, respectively.

Dairy products are also reported as the main source of estrogens in human diet (60-70\%). A most extreme concentration of absolute estrone (sum of free and conjugated structures) in butter $(1.47 \mathrm{ng} / \mathrm{g})$, followed by cream, gouda cheese, yogurt, and milk $(0.26$, $0.17,0.16$, and $0.13 \mathrm{ng} / \mathrm{g}$ or $\mathrm{ng} / \mathrm{mL}$, respectively) was observed (Hartmann et al., 1998). The concentrations of estrogen and progesterone in various dairy products have been described in the Table 2 .

Pesticides: The main source of pesticides in milk and milk products is the livestock feed contaminated with pesticides. Among them the most harmful and common pesticides are dichloro diphenyl trichloroethane (DDT), dichloro diphenyl dichloroethane (DDD), chlorinated cyclodienes (aldrin, dialdrin, heptachlor etc), hexachlorocyclohexane (lindane), polychlorinated biphenyls(PCB) and dioxins. The accumulation of the DDT occurs in fatty tissues and transferred into milk and milk products and produces adverse health effects to the consumers. Wong and Lee (1997) stated that the pesticide residues persist in the environment and cause food borne illness through consumed foods. As much as $20 \%$ of an ingested chlorinated hydrocarbon is discharged in milk. Chlorinated hydrocarbons hold fast to drain fat and spread a higher extent of the insecticides (Hubbert et al., 1996). The details of pesticides found in milk and milk products are presented in Table 3.

Mycotoxins: The main mycotoxin found in the milk is Aflatoxin M1 (AFM1) which is metabolized by the moulds and the feed contains Aflatoxin B1 (AFB1) (Van Egmond, 1989; Wood, 1991). The improper storage, high damping during harvesting and improper drying are the main reasons for production of Aflatoxin B1. In 1993, International Agency for Research on Cancer (IARC) of WHO included AFB1 and AFM1 as cancer-causing substances (Cathey et al., 1994; Dragacci et al., 1995).

Pasteurization was proven as one of the ineffective measures against Aflatoxin M1 formation (Jahed, 2006). AFM1 with different levels could be detectable in dairy items. Therefore, milk and other dairy items must be monitored consistently for AFM1.

Table 2. The concentrations $(\mathrm{ng} / \mathrm{mL}$ or $\mathrm{ng} / \mathrm{g}$ ) of progesterone, estrogens in milk and milk products

\begin{tabular}{lccccc}
\hline Hormones & Milk & Butter & Cream & Gouda cheese & Yoghurt \\
\hline Esterone & 0.13 & 1.47 & 0.26 & 0.17 & 0.16 \\
17ß-estradiol & 0.02 & 0.3 & 0.03 & 0.03 & 0.02 \\
Progesterone & 9.81 & 141 & 48.6 & 44.2 & 13.3 \\
\hline
\end{tabular}

Source: Malekinejad and Rezabakhsh, 2015 
Heavy metals: Various data collected from all over the India about the heavy metals found in milk and milk products are shown in the Table No. 4.

\section{Public Health Concerns}

The presence of chemical residues in milk and milk products have become a public health concern for the consumers. Excessive use of antibiotics may cause toxicity in consumers. Antibiotic residues are the factors for few adverse conditions like aplasia of the bone marrow (e.g. chloramphenicol) (Mitchell et al., 1998; Mitchell et al., 1995; Jones and Seymour, 1988) and cancer (oxytetracycline and furazolidone) (Mitchell et al., 1998).
Various clinical signs like nausea, vomiting and gastrointestinal disturbance may occur due to antibiotic residues.

Pesticides, for example hexachlorocyclohexane ( $\mathrm{HCHs}$ ), can cause harms on central nervous system, reproductive and endocrine. By high lipophilicity and long disposal half-lives, organochlorine pesticides portray some effects of neurotoxin, birth absconds, conduct effects, regenerative effects, disease, interruption of the ordinary homeostasis of the endocrine capacities (Alvarado and Perez, 1998). Mycotoxins can likewise be seen in milk and dairy items and can make general medical issues in people.

Table 3. Pesticides with mean level found in milk and milk products

\begin{tabular}{llll}
\hline Pesticides & Types of dairy products & $\begin{array}{l}\text { Mean level } \\
(\mathbf{m g} / \mathbf{k g} \text { of fat) }\end{array}$ & References \\
\hline Dieldrin & Ras cheese & $0.0039-0.0068$ & Aman and Bluethgen, 1997 \\
& Damietta cheese & 0.0025 & Aman and Bluethgen, 1997 \\
\hline DDT & Milk & 0.159 & Waliszewski et al., 1997 \\
& Butter & 0.049 & Waliszewski et al., 1997 \\
& Milk powder & 0.0546 & Aman and Bluethgen, 1997 \\
\hline HCB & Raw milk & 0.016 & Martinez et al., 1997 \\
& Milk powder & 0.00656 & Aman and Bluethgen, 1997 \\
& Ras cheese & 0.0037 & Aman and Bluethgen, 1997 \\
& Damietta cheese & 0.0045 & Aman and Bluethgen, 1997 \\
& Spanish pasteurized milk & 0.007 & Martinez et al., 1997 \\
\hline HCH & Milk & 0.094 & Waliszewski et al., 1997 \\
& Spanish pasteurized milk & 0.015 & Martinez et al., 1997 \\
& Milk powder & 0.0149 & Aman and Bluethgen, 1997 \\
& Ras cheese & 0.00865 & Aman and Bluethgen, 1997 \\
& Damietta cheese & 0.0115 & Aman and Bluethgen, 1997 \\
& Butter & 0.093 & Waliszewski et al., 1997 \\
\hline Aldrin-dieldrin & Cheese & 0.2 ng/g & Martinez et al., 1997 \\
& Milk & $0.0074-0.0271$ & Aman and Bluethgen, 1997 \\
& Milk powder & 0.0025 & Aman and Bluethgen, 1997 \\
\hline
\end{tabular}

HCB: Hexachlorobenzene; HCH: Hexachlorocyclohexane; DDT: Dichlorodiphenyltrichloroethen 
Chemical residues in milk

Table 4. Heavy metals in milk found in all over the India

\begin{tabular}{|c|c|c|c|c|c|c|}
\hline Place & Milk Type & $\begin{array}{l}\text { Sample } \\
\text { (n) }\end{array}$ & $\begin{array}{l}\text { Range } \\
(\mu \mathrm{g} / \mathbf{m L})\end{array}$ & $\begin{array}{l}\text { Mean } \\
(\mu \mathrm{g} / \mathrm{mL})\end{array}$ & $\begin{array}{l}\text { Analytical } \\
\text { method }\end{array}$ & Reference \\
\hline $\begin{array}{l}\text { Palghar } \\
\text { (Maharashtra) }\end{array}$ & Buffalo milk & 28 & $\begin{array}{l}\mathrm{Zn}-0.111-7.23 \\
\mathrm{Fe}-0.111-7.723 \\
\mathrm{~Pb}-0.065-0.137 \\
\mathrm{Ba}-0.148-0.304 \\
\mathrm{Mn}-0.027-0.406 \\
\mathrm{Cr}-0.014-1.606 \\
\mathrm{Ni}-0.04-0.749\end{array}$ & $\begin{array}{l}4.23 \\
4.25 \\
0.089 \\
0.253 \\
0.124 \\
0.278 \\
0.094 \\
\end{array}$ & ICP-AES & $\begin{array}{l}\text { Nirgude and } \\
\text { Bhagure, } 2015\end{array}$ \\
\hline Delhi & $\begin{array}{l}\text { Branded } \\
\text { milk }\end{array}$ & - & $\mathrm{Zn}$ & 2.28 & $\begin{array}{l}\text { Voltammetric } \\
\text { determination }\end{array}$ & Raina et al., 2013 \\
\hline Bangalore & Cow milk & - & $\begin{array}{l}\mathrm{Fe}-0.33 \\
\mathrm{Zn}-1.83 \\
\mathrm{Cd}-0.02 \\
\end{array}$ & $\begin{array}{l}- \\
- \\
-\end{array}$ & AAS & $\begin{array}{l}\text { Lokeshwari and } \\
\text { Chandrappa, } 2006\end{array}$ \\
\hline $\begin{array}{l}\text { Singhbhum } \\
\text { (Jharkhand) }\end{array}$ & Cow milk & 60 & $\begin{array}{l}\mathrm{Fe}-0.2-13.2 \\
\mathrm{Mn}-0.17-0.59 \\
\mathrm{Zn}-1.66-7.13 \\
\mathrm{Cu}-0.23-2.03 \\
\mathrm{Ni}-0.31-0.63\end{array}$ & $\begin{array}{l}4.91 \\
0.29 \\
4.77 \\
0.56 \\
0.48\end{array}$ & AAS & Giri et al., 2011 \\
\hline Hyderabad & Buffalo milk & 30 & $\begin{array}{l}\mathrm{Pb}- \\
\mathrm{Zn}-\end{array}$ & $\begin{array}{l}0.22 \\
3.96 \\
\end{array}$ & F-AAS & Shailaja et al., 2014 \\
\hline Mumbai & $\begin{array}{l}\text { Cow milk of } \\
\text { different } \\
\text { brands }\end{array}$ & 15 & $\begin{array}{l}\mathrm{Cu}-0.039-37.29 \\
\mathrm{Zn}-0.496-0.786 \\
\mathrm{Cr}-0.013-0.175 \\
\mathrm{~Pb}-0.139-5.904 \\
\mathrm{Hg}-0.015-0.023\end{array}$ & $\begin{array}{l}- \\
- \\
- \\
- \\
-\end{array}$ & ICP-AES & Zodape et al., 2012 \\
\hline $\begin{array}{l}\text { Hosur, } \\
\text { (Tamilnadu) }\end{array}$ & Goat milk & 144 & $\begin{array}{l}\text { As-0.082-0.056 } \\
\mathrm{Cd}-0.030-0.016 \\
\mathrm{~Pb}-0.064-0.052 \\
\mathrm{Hg}-0.007-0.004 \\
\mathrm{Ni}-0.069-0.067\end{array}$ & $\begin{array}{l}- \\
- \\
- \\
- \\
-\end{array}$ & ICP-OES & $\begin{array}{l}\text { Dhanalakshmi and } \\
\text { Gawdaman, } 2013\end{array}$ \\
\hline $\begin{array}{l}\text { Tiruvallur } \\
\text { (Tamilnadu) }\end{array}$ & Buffalo milk & 216 & $\mathrm{~Pb}-\mathrm{ND}-0.19$ & 8.62 & AAS & $\begin{array}{l}\text { Sahayaraj and } \\
\text { Ayyadurai, } 2009\end{array}$ \\
\hline Vadodara & $\begin{array}{l}\text { Milk and milk } \\
\text { product } \\
\text { Branded milk }\end{array}$ & 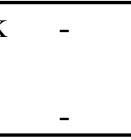 & $\begin{array}{l}\text { Cd- } \\
\text { Cd- }\end{array}$ & $\begin{array}{l}1.51 \\
0.23 \\
\end{array}$ & AAS & $\begin{array}{l}\text { Chandorkar and } \\
\text { Deota, } 2013\end{array}$ \\
\hline $\begin{array}{l}\text { Bombay } \\
\text { City }\end{array}$ & $\begin{array}{l}\text { Commercial } \\
\text { milk } \\
\text { Cow milk }\end{array}$ & 75 & $\begin{array}{l}\mathrm{Zn}-3.177 \\
\mathrm{~Pb}-0.0017 \\
\mathrm{Cu}-0.0017\end{array}$ & $\begin{array}{l}- \\
- \\
-\end{array}$ & AAS & Tripathi et al., 1999 \\
\hline $\begin{array}{l}\text { Various parts } \\
\text { of India } \\
\end{array}$ & $\begin{array}{l}\text { from } \mathrm{Pb}, \mathrm{Zn} \\
\text { Smelter area }\end{array}$ & 21 & $\mathrm{~Pb}-0.13-2.70$ & 0.844 & AAS & Various parts of India \\
\hline
\end{tabular}




\section{Chemical residues-the Indian scenario}

Different workers found pesticide and antibiotic residues in milk and milk products collected from different areas in India. Ravi Kumar et al. (2018) tested 538 milk samples for antibiotic residues collected from 21 towns of Hassan Taluk, Hassan District, Karnataka and found $63 \%$ of milk samples contained at least one deposits; $27 \%$ contained 2 residues; $11 \%$ contained at least 3 deposits of antibiotic medications and sulphonamides. According to Mahmoudi et al. (2013) antibiotic residues are found in higher amount in winter season than the summer season. Kaya and Filazi (2010) identified antibiotic residues in raw milk and pasteurized milk like penicillin $\mathrm{G}$, oxytetracycline, gentamicin, streptomycin and neomycin. By using flourometric method, oxytetracycline was detected in 71 milk samples out of 91 samples from individual animals and 9 samples out of 101 market samples in Hyderabad, India (Sudershan and Ramesh, 1995). In Punjab, eighteen milk samples out of total 133 milk samples were analysed and found to have tetracyclines residues (Kaya and Filazi, 2010). Khanal et al. (2018) using the subjective and

\section{REFERENCES}

Alvarado Y and Perez CA, 1998. The use of biocides: An environmental problem. Interciencia, 23: 20-25

Aman IM and Bluethgen A, 1997. Occurrence of residues of organochlorine pesticides and polychlorinated biphenyls in milk and dairy products from Egypt. Milchwissenschaft, 52(7): 394-399

Aytenfsu S, Mamo G and Kebede B, 2016. Review on chemical residues in milk and their public health concern in Ethiopia. J Nutr Food Sci, 6(4): $1-11$ semi-quantitative investigation with rapid screening kits, stated that $23 \%$ tests were certain for antibiotic residues in the fresh milk for penicillin and sulphonamide. However, HPLC analysis showed $81 \%$ samples positive for amoxicillin, $41 \%$ for sulfadimethoxine, $27 \%$ for penicillin $\mathrm{G}$ and $12 \%$ for ampicillin for 140 milk samples.

\section{Conclusion}

The main reasons behind the presence of chemical residues in milk and milk products are the poor milk handling, environmental contamination, uncontrolled use of antibiotics, overuse of pesticides and insecticides etc. These chemical residues cause several toxic effects to the consumers through the foods. The manufactures of dairy products and milk parlours should obey the permissible limit of different chemical residues recommended by $\mathrm{FAO}$, WHO, CAC, FSSAI etc. Awareness programmes should be conducted for consumers as well as the milk and milk product producers on a regular basis towards maintaining safety and quality of milk and milk products by restricting the residue level to a maximum permissible limit.

Cathey CG, Huang ZG, Sarr AB, Clement BA and Phillips TD, 1994. Development and evaluation of a minicolumn assay for the detection of aflatoxin M1 in milk. J Dairy Sci, 77(5): 12231231

Chandorkar S and Deota P, 2013. Heavy metal content of foods and health risk assessment in the study population of Vadodara. Curr World Environ, 8(2): 291-297

Chaves J and Saif M, 2011. IGF system in cancer: from bench to clinic. Anti-Cancer Drugs, 22(3): 206212 
Dhanalakshmi B and Gawdaman G, 2013. Determination of heavy metals in goat milk through ICP-OES. Asian J Dairy Food Res, 32: 186-190

Dragacci S, Gleizes E, Fremy JM and Candlish AA, 1995. Use of immunoaffinity chromatography as a purification step for the determination of aflatoxin M1 in cheeses. Food Addit Contam, 12(1): 59-65

FAO/WHO, 1993. Residues of some veterinary drugs in animals and foods. Monographs prepared by the forty-third meeting of the Joint FAO/WHO Expert Committee on Food Additives. FAO Food Nutr Pap, 41/5

FAO/WHO, 1995. Residues of some veterinary drugs in animals and foods. Monographs prepared by the forty-third meeting of the Joint FAO/WHO Expert Committee on Food Additives. FAO Food Nutr Pap, 41: 1-112

FDA USA, 1996. Evaluation and use of milk. Antimicrobial drug screening tests report. Centre for food safety and applied nutrition. Feed and Drug Control Authorities Prime Connection, Rockville, USA

Folly M and Machado S, 2001. Antibiotic residues determination, using microbial inhibition, protein binding and immunoassays methods, in pasteurized milk commercialized in the northern region of Rio de Janeiro State, Brazil. Cienc Rural, 31: 95-98

FSSA, 2006. Food Safety and Standards for Contaminants, Toxins and Residues, Second Amendment Regulations

Giri, S, Singh G, Jha VN and Tripathi RM, 2011. Risk assessment due to ingestion of natural radionuclides and heavy metals in the milk samples: A case study from a proposed uranium mining area, Jharkhand. Environ Monit Assess, 175(1-4): 157-166

Hartmann S, Lacorn M and Steinhart H, 1998. Natural occurrence of steroid hormones in food. Food Chem, 62(1): 7-20
Hubbert WT, Hagstad HV, Spangler E, Hinton MH and Hughes KL, 1996. Food Safety and Quality Assurance (Foods of Animal Origin), (2nd edn.), Iowa State University Press, Ames, 8: pp171179, 239-273

Ikeda M, Zhang ZW, Moon CS, Imai Y, Watanabe T et al., 1996. Background exposure of general population to cadmium and lead in Tainan city, Taiwan. Arch Environ Contam Toxicol, 30: 121-126

Jahed KGR, 2006. Aflatoxin M1 related to consumption of contaminated milk and dairy products. J Iran Vet Council, Iran

Jensen RG, 1995. Handbook of Milk Composition. Academic Press, Inc., pp887-900

Jones GM and Seymour EH, 1988. Cowside antibiotic residue testing. J Dairy Sci, 71(6): 1691-1699

Kaya SE and Filazi A, 2010. Determination of antibiotic residues in milk samples. Kafkas. Univ Vet Fak Derg, 16: 31-35

Khanal BK, Sadiq MB, Singh M and Anal AK, 2018. Screening of antibiotic residues in fresh milk of Kathmandu valley, Nepal. J Environ Sci Health B, 53(1):57-86

Lokeshwari H and Chandrappa GT, 2006. Impact of heavy metal contamination of Bellandur Lake on soil and cultivated vegetation. Curr Sci, 91(5): 622- 627

Malekinejad H and Rezabaksh A, 2015. Hormones in dairy foods and their impact on public healthA narrative review article. Iran J Public Health, 44(6): 742-758

Mahmoudi R, Asadpour R, Alamoti MP, GolchinA, Kiyani R et al., 2013. Raw cow milk quality: Relationship between antibiotic residue and somatic cell count. Int Food Res J, 20(6): 33473350

Martinez P, Angulo R, Pozo R and Jordal M, 1997. Levels of hexachlorobenzene $(\mathrm{HCB})$ in raw milk. Alimentaria, 35: 99-101 
Mitchell JM, Griffiths MW, McEwen SA, McNabWB, and Yee AJ, 1998. Antimicrobial drug residues in milk and meat: causes, concerns, prevalence, regulations, tests, and test performance. J Food Protocol, 61: 742-756

Mitchell M, Bodkin B and Martin J, 1995. Detection of beta-lactam antibiotics in bulk tank milk. $\mathrm{J}$ Food protect, 58: 577-578

Nirgude NT and Bhagure GR, 2015. Heavy metals and mineral elements in milk of buffaloes at Boisar-Tarapur industrial area, Palghar district, Maharashtra, India. American Int Contem Sci Res, 2(5): 70-77

Ontsouka CE, Bruckmaier RM and Blum JW, 2003. Fractionized milk composition during removal of colostrum and mature milk. J Dairy Sci, 86 (6): 2005-2011

Raghunath R, Tripathi RM, Khandekar RN and Nambi KS, 1997. Retention times of $\mathrm{Pb}, \mathrm{Cd}$, $\mathrm{Cu}$ and $\mathrm{Zn}$ in children's blood. Sci Total Environ, 207: 133-139

Raina A, Raj J and Dogra TD, 2013. Zinc (Zn) Analysis in Milk by Microwave Oven Digestion and Differential Pulse Anodic Stripping Voltametry (DPASV) Technique. In E3S Web of Conferences (Vol. 1). EDP Sciences

Ravi Kumar C, Ranjith J, Pavankumar KN, Prakash N, Abbas MH et al., 2018. Screening of antibiotic residues in cattle milk by paper strip assay. Bull Env Pharmacol Life Sci, 7 (11): 20-25

Sahayaraj PA and Ayyadurai K, 2009. Bioaccumulation of lead in milk of buffaloes from Cooum River Belt in Chennai. J Environ Biol, 30(5): 651-654

Shailaja M, Reddy YS, Kalakumar BDP, Brinda SA, Manohar G et al., 2014. Lead and trace element levels in milk and blood of buffaloes (Bubalus bubalis) from Hyderabad, India. Bull Environ Contam Toxicol, 92(6): 698-702
Sudershan RV and Bhat RV 1995. A survey on veterinary drug use and residues in milk in Hyderabad, Food Addit Contam, 12(5): 645650

Tennant DR, 1997. Food Chemical Risk Analysis. Blakie Academic and Professional. (1st edn.), Chapman and Hall, UK, pp381-398

Thornley JR, 2001. Got hormone-free milk: your state may have enough interest to let you Know. Indiana Law J, 76: 785

Tripathi RM, Raghunath R, Sastry VN and Krishnamoorthy TM, 1999. Daily intake of heavy metals by infants through milk and milk products. Sci Total Environ, 227(2-3): 229-235

Van Egmond HP, 1989. Aflatoxin M1: Occurrence, toxicity, regulation in mycotoxin in dairy products. Elsevier Applied Publishers Ltd., London, pp11-55

Volkmer BG, 2005. Influence of nitrate levels in drinking water on urological malignancies: a community-based cohort study. BJU Int., 95: 972-976

Waliszewski SM, Pardio VT, Waliszewski KN, Chantiri JN, Aguirre AA et al., 1997. Organochlorine pesticide residues in cow's milk and butter in Mexico. Sci Total Environ, 208(12): $127-132$

Wong SK and Lee WO, 1997. Survey of organochlorine pesticide residues in milk in Hong Kong (1993-1995). J AOAC Int, 80(6): 1332-1335

Wood GE, 1991. Aflatoxin M1. In: Mycotoxins and Phytoalexins, Sharma RP, Salunkhe DK (edn.), CRC, London, pp145-163

Zodape GV, Dhawan VL and Wagh RR, 2012. Determination of metals in cow milk collected from Mumbai city, India. Bionano Frontier, Special issue, Eco Revolution Colombo Srilanka, pp270-274

Article received on 18.10.2019 and accepted for publication on 16.11.2019 